\title{
IMPLEMENTASI PEMBELAJARAN BERBASIS PROYEK PADA MATERI PENCEMARAN LINGKUNGAN UNTUK MENINGKATKAN LITERASI STEM SISWA SMA
}

\author{
Ariani Aninda ${ }^{1)}$, Anna Permanasari ${ }^{2)}$, Didit Ardianto ${ }^{3)}$ \\ 1).SMAN 1 Cigombong Kab. Bogor \\ 2), 3) Program Studi Pendidikan IPA, Sekolah Pascasarjana Universitas Pakuan \\ *E-mail: arianianinda@gmail.com
}

\begin{abstract}
Abstrak: Tujuan dari penelitian ini adalah memperoleh gambaran penerapan model pembelajaran berbasis proyek pada materi pencemaran lingkungan yang dapat meningkatkan Literasi STEM siswa SMA serta memperoleh gambaran peningkatan Literasi STEM siswa setelah implementasi model pembelajaran berbasis proyek. Penelitian ini menggunakan metode kuantitatif menggunakan desain penelitian quasi eksperimental dengan rancangan The Matching only Pretest-Posttest Control Group Design. Subjek pada penelitian ini adalah siswa kelas X SMAN 1 Cigombong dengan pengambilan menggunakan dua kelompok subjek dengan menggunakan teknik purposive sampling. Sampel kelas eksperimen berjumlah 35 orang dan kelas kontrol berjumlah 36 orang sehingga keseluruhan subjek penelitian berjumlah 71 orang. Keterlaksanaan pembelajaran diobservasi menggunakan lembar observasi aktifitas guru dan siswa. Hasil Literasi STEM setiap kelompok diukur dengan menggunakan tes pilihan ganda berjumlah 25 soal yang memuat indikator literasi STEM. Respon siswa terhadap model pembelajaran dijaring dengan menggunakan angket skala likert. Dari hasil analisis observasi diperoleh bahwa keterlaksanaan pembelajaran berlangsung dengan sangat baik, prosentase keaktifan siswa juga menunjukkan hasil sangat baik. Hasil analisis data diketahui bahwa pencapaian rerata $N_{-}$Gain Literasi STEM pada kelas eksperimen termasuk kategori sedang. Sedangkan kelas kontrol memperoleh pencapaian literasi STEM termasuk dalam kategori rendah. Hasil Uji beda t-test menunjukkan bahwa perolehan STEM literasi lebih baik dibandingkan dengan kelas kontrol. Sebagian besar siswa memberikan tanggapan positif terhadap model pembelajaran berbasis proyek, mereka merasa senang, puas dan meningkatkan motivasi dalam belajar.
\end{abstract}

Kata Kunci: Literasi STEM, Pembelajaran Berbasis Proyek, Pencemaran Lingkungan.

\section{PENDAHULUAN}

Bidang sains, teknologi, enjiniring dan matematika dapat menjadi faktor penentu dan pendorong perkembangan ekonomi, program pendidikan dan perlindungan yang kuat bagi suatu negara. Bidang tersebut diharapkan menjadi kunci sukses bagi pembangunan suatu negara, terutama negara berkembang 
seperti Indonesia. Untuk tetap bisa bersaing secara global, banyak negara menyerukan peningkatan studi di bidang Sains, Teknologi, Teknik dan Matematika (STEM) di semua tingkat pendidikan. Mengajar STEM di pendidikan dasar dan menengah dapat membantu siswa tertarik pada karir STEM dan membangun angkatan kerja berpendidikan STEM yang dapat digunakan untuk memenuhi tuntutan bisnis dan industri dalam ekonomi yang kompleks dan berbasis teknologi. Selanjutnya, angkatan kerja berpendidikan STEM yang bekerja dengan profesional STEM lainnya dari seluruh dunia akan dibutuhkan untuk menyelesaikan banyak masalah dan masalah global misalnya pemanasan global, polusi udara dan air bersih, air minum bersih, dan ketahanan pangan.

Semua mata pelajaran Sains seharusnya memberikan kontribusi pada upaya meningkatkan kemampuan Literasi STEM. Belajar Sains dapat ditempuh dengan menambahkan teknologi enjiniring dan matematika. Dalam mata pelajaran Biologi ada beberapa pokok bahasan yang dapat digunakan sebagai wahana untuk meningkatkan Literasi STEM Siswa salah satunya yaitu materi Pencemaran Lingkungan pada Kelas X semester 2. Materi ini merupakan materi biologi yang sarat dengan aplikasi pengetahuan, keterampilan serta sikap ilmiah. Selain itu, materi ini sangat dekat dengan lingkungan siswa sehari-hari, sehingga memudahkan siswa untuk melakukan analisis dan berpikir tentang rancangan serta teknologi terkait materi tersebut. Pembelajaran berbasis proyek pada materi pencemaran lingkungan sangat potensial untuk memberikan pembelajaran yang bermakna, dapat melatih kemampuan siswa untuk melakukan pemecahan masalah melalui sebuah proyek yang terintegrasi dengan satu atau beberapa bidang keilmuan lain seperti sains, enjiniring, dan teknologi.

Berdasarkan hasil observasi yang dilakukan di kelas X salah satu SMA di Kabupaten Bogor, ditemukan permasalahan pembelajaran pada materi lingkungan bahwa guru belum menerapkan strategi belajar yang inovatif dengan menstimulus siswa berperan aktif dan ikut serta dalam pemecahan masalah. Pembelajaran yang dilakukan masih menekankan pada penguasaan kemampuan berpikir tingkat rendah. Pembelajaran biologi sebagai sekedar transfer of knowledge yang dimiliki guru kepada peserta didik dengan hapalan-hapalan teori untuk menjawab soal ujian tetapi seringkali siswa tidak sanggup untuk menerjemahkannya ke dalam realitas yang ada di sekelilingnya. Oleh karena itu, pembelajaran yang dilakukan perlu menekankan pengembangan kemampuan berpikir tingkat tinggi agar siswa mampu mengembangkan potensinya secara utuh, dan diharapkan dapat meningkatkan literasi STEM. Untuk mengatasi permasalahan di atas pembelajaran di sekolah hendaknya merancang pembelajaran yang efektif. Halhal yang perlu dipertimbangan guru dalam merancang pembelajaran dengan memilih pendekatan, strategi, metode, dan teknik pembelajaran yang bisa menjawab tantangan yang akan dihadapi siswa di masa yang akan datang. 
Kurikulum 2013 telah memberikan acuan dalam pemilihan model pembelajaran yang sesuai dengan pendekatan saintifik dan mempersiapkan siswa menghadapi tantangan jaman. Model pembelajaran yang dimaksud salah satunya adalah pembelajaran berbasis proyek. Penerapan pembelajaran berbasis proyek dalam pembelajaran sains dari hasil penelitian dapat meningkatkan hasil belajar kognitif (Baran dan Maskan, 2010), membentuk sikap dan prilaku peduli terhadap lingkungan (Kılınç, 2010; Tseng, et al, 2013), keterampilan proses sains (Özer dan Özkan, 2012), dan pembelajaran yang efektif (Cook, 2012).

Penelitian Craig (2015: hlm 4) menyebutkan bahwa salah satu model pembelajaran yang efektif untuk memfokuskan kemampuan di bidang STEM adalah pembelajaran berbasis proyek. Pembelajaran berbasis proyek lebih cocok untuk pengajaran interdisipliner karena secara alami melibatkan banyak keterampilan akademik yang berbeda, seperti membaca, menulis, dan matematika dan cocok untuk membangun pemahaman konseptual melalui asimilasi mata pelajaran yang berbeda (Capraro, 2013, hlm. 52). Selain model Pembelajaran berbasis proyek, pembelajaran saat ini perlu mengikuti perkembangan zaman di era globalisasi dengan mengintegrasikan Science, Technology, Engineering, dan Mathematics (STEM) dalam membangun keterampilan abad 21. "Beberapa keuntungan dari pembelajaran STEM yaitu membuat peserta didik menjadi pemecah masalah yang lebih baik, inovator, penemu, pemikir logis, mandiri, dan seorang yang mempunyai kemampuan literasi teknologi (Morrison dalam Stohlmann, et al., 2012, hlm. 29).

Pertanyaan penelitian:

1. Bagaimana keterlaksanaan pembelajaran berbasis proyek pada materi pencemaran lingkungan untuk meningkatkan literasi STEM siswa SMA?

2. Bagaimana peningkatan literasi STEM siswa SMA setelah mendapatkan pembelajaran berbasis proyek pada materi Pencemaran Lingkungan?

\section{METODE}

Penelitian ini menggunakan metode kuantitatif yaitu quasi eksperimen. Penelitian yang digunakan adalah menggunakan desain penelitian quasi eksperimental dengan rancangan The Matching only Pretest-Posttest Control Group Design (Fraenkel \& Wallen, 2009: 271) Rancangan penelitian menggunakan dua kelompok subjek yaitu kelompok eksperimen dan kelompok kontrol, kelompok eksperimen tersebut diberi perlakuan selanjutnya dilakukan pengamatan.

Penelitian ini dilakukan untuk memperoleh informasi Literasi STEM siswa melalui penerapan model pembelajaran berbasis proyek. Desain penelitian quasi eksperimental dengan rancangan The Matching only Pretest-Posttest Control Group Design dapat digambarkan sebagai berikut : 
Tabel 1. Desain Penelitian

\begin{tabular}{lclcc}
\hline \multicolumn{1}{c}{ Kelas } & Pretest & \multicolumn{1}{c}{ Variabel Bebas } & Posttest & Peningkatan \\
\hline Eksperimen & T1 & X (dengan perlakuan) & T2 & Y \\
\hline Kontrol & T3 & X' (tanpa perlakuan) $^{\prime}$ & T4 & Y' \\
\hline
\end{tabular}

$\mathrm{X}=$ Pembelajaran biologi dengan model pembelajaran berbasis proyek

$\mathrm{X}^{\prime} \quad=$ Pembelajaran biologi konvensional

$\mathrm{T} 1=$ Instrumen untuk melihat kemampuan awal Literasi STEM siswa

$\mathrm{T} 3$ = Instrumen untuk melihat kemampuan awal Literasi STEM siswa

$\mathrm{T} 2=$ Instrumen untuk melihat kemampuan akhir Literasi STEM siswa setelah mendapatkan model pembelajaran berbasis proyek

$\mathrm{T} 4=$ Instrumen untuk melihat kemampuan akhir Literasi STEM siswa setelah mendapatkan pembelajaran konvensional

\section{Subjek Penelitian}

Mengacu pada Fraenkel dan Wallen (2009:90) Populasi adalah kelompok besar yang mengaplikasikan seluruh hasil penelitian. Populasi penelitian ini adalah siswa kelas X Peminatan MIPA SMA Negeri 1 Cigombong Kabupaten Bogor. Teknik pengambilan sampel dalam penelitian ini adalah teknik pengambilan Purposive Sampling (Fraenkel \& Wallen. 2009: 99) yaitu sampel dipilih dengan tujuan tertentu. Peneliti memilih sampel untuk kelas eksperimen yaitu kelas X-1 sebanyak 35 orang dan untuk kelas kontrol yaitu kelas X-4 sebanyak 36 0rang.

\section{Teknik Pengumpulan Data}

Penelitian ini menggunakan teknik penilaian yaitu tes dan nontes. Untuk instrumen tes yaitu Tes Literasi STEM sedangkan untuk instrumen non tes yaitu Tanggapan respon siswa terhadap model pembelajaran berbasis proyek.

Tabel 2. Teknik Pengumpulan Data

\begin{tabular}{llll}
\hline Sumber Data & \multicolumn{1}{c}{ Jenis Data } & $\begin{array}{c}\text { Teknik Pengumpulan } \\
\text { data }\end{array}$ & \multicolumn{1}{c}{ Keterangan } \\
\hline Siswa & Literasi STEM & $\begin{array}{l}\text { Tes pilihan ganda } \\
\text { (pretest dan posttest })\end{array}$ & $\begin{array}{l}\text { Dilakukan di } \\
\text { awal dan di akhir } \\
\text { proses } \\
\text { pembelajaran }\end{array}$ \\
\hline Guru & $\begin{array}{l}\text { Aktivitas guru dalam } \\
\text { mengelola } \\
\text { pembelajaran }\end{array}$ & $\begin{array}{l}\text { Observasi guru dalam } \\
\text { mengelola pembelajaran }\end{array}$ & $\begin{array}{l}\text { Selama } \\
\text { pembelajaran }\end{array}$ \\
\hline Siswa & $\begin{array}{l}\text { Frekuensi aktivitas } \\
\text { siswa selama proses } \\
\text { pembelajaran }\end{array}$ & $\begin{array}{l}\text { Observasi aktivitas } \\
\text { siswa selama proses } \\
\text { pembelajaran }\end{array}$ & $\begin{array}{l}\text { Selama } \\
\text { pembelajaran }\end{array}$ \\
\hline Siswa & $\begin{array}{l}\text { Respon siswa } \\
\text { terhadap model } \\
\text { pembelajaran }\end{array}$ & Angket respon siswa & $\begin{array}{l}\text { Setelah seluruh } \\
\text { proses pembe- } \\
\text { lajaran selesai }\end{array}$ \\
\hline
\end{tabular}




\section{HASIL DAN PEMBAHASAN}

\section{Keterlaksanaan Pembelajaran dengan Menggunakan Model Pembelajaran berbasis proyek}

Implementasi pembelajaran biologi menggunakan model pembelajaran berbasis proyek pada materi Pencemaran Lingkungan dilakukan pada bulan Mei semester II. Pembelajaran ini dilakukan selama 3 pertemuan masing-masing 3JP (1 JP @ 45 menit) yang terdiri dari 6 sintaks pembelajaran berbasis proyek. Pertemuan pertama merupakan fase 1, pertemuan kedua terdiri dari fase 2 dan 3 kemudian pertemuan ketiga terdiri dari fase 4,5 dan 6. Selama proses pembelajaran Biologi dengan materi pencemaran lingkungan menggunakan model pembelajaran berbasis proyek dilakukan observasi terhadap keterlaksanaan pembelajaran dengan menggunakan lembar observasi yang dilakukan oleh observer sebanyak satu orang. Selain itu dilakukan pula perekaman dengan menggunakan alat dokumentasi. Aspek yang diamati dalam keterlaksanaan pembelajaran yaitu aktivitas guru dalam mengelola pembelajaran dan aktivitas siswa selama mengikuti proses pembelajaran yang diterapkan dalam kelas serta kesesuaiannya dengan RPP yang dirancang. Berikut ini hasil dan pembahasan keterlaksanaan pembelajaran biologi dengan menggunakan model pembelajaran berbasis proyek.

Keterlaksanaan pembelajaran ini diobservasi untuk mengetahui apakah sintaks pembelajaran yang dirancang terlaksana atau tidak dalam setiap pembelajaran, sehingga dapat dilihat kemungkinan pengaruhnya terhadap hasil akhir literasi STEM siswa. Berikut adalah data hasil observasi keterlaksanaan sintaks pembelajaran dengan model pembelajaran berbasis proyek.

Tabel 3. Keterlaksanaan Sintaks Model Pembelajaran Berbasis Proyek

\begin{tabular}{llcc}
\hline No & \multicolumn{1}{c}{$\begin{array}{c}\text { Sintaks Pembelajaran } \\
\text { Berbasis Proyek }\end{array}$} & $\begin{array}{c}\text { Persentase } \\
\text { Keterlaksanaan }\end{array}$ & Kategori \\
\hline 1. & Start with the essential questions & $100 \%$ & Sangat baik \\
\hline 2. & Design a plan for the project & $100 \%$ & Sangat baik \\
\hline 3. & $\begin{array}{l}\text { Monitoring the students and the } \\
\text { progress of the project }\end{array}$ & $100 \%$ & Sangat baik \\
\hline 4. & Assess the outcome & $100 \%$ & Sangat baik \\
\hline 5. $\quad$ Evaluate the experience & $100 \%$ & Sangat baik \\
\hline RERATA & $\mathbf{1 0 0 \%}$ & Sangat baik \\
\hline
\end{tabular}

Data pada Tabel 4. menunjukkan bahwa secara keseluruhan sintaks pembelajaran pembelajaran berbasis proyek terlaksana dengan persentase $100 \%$ yaitu dengan kategori sangat baik. Hal ini menunjukkan bahwa dalam proses 
pembelajaran peneliti konsisten menerapkan sintaks model pembelajaran berbasis proyek.

Tabel 4. Hasil Observasi Aktifitas Siswa

\begin{tabular}{|c|c|c|c|c|c|}
\hline \multirow[b]{2}{*}{ No } & \multirow[b]{2}{*}{ Aktifitas Siswa } & \multicolumn{3}{|c|}{ Aktifitas Siswa (\%) } & \multirow{2}{*}{$\underset{\%}{\text { Rerata }}$} \\
\hline & & $\begin{array}{c}\text { Pertemuan } \\
\text { I }\end{array}$ & $\begin{array}{l}\text { Pertemuan } \\
\text { II }\end{array}$ & $\begin{array}{l}\text { Pertemuan } \\
\text { III }\end{array}$ & \\
\hline 1 & Mengemukakan Ide baru & 82,86 & 76,19 & 76,19 & 78,41 \\
\hline 2 & Bertukar Informasi & 83,81 & 85,71 & 83,81 & 84,44 \\
\hline 3 & $\begin{array}{l}\text { Mempresentasikan hasil } \\
\text { diskusi kelompok }\end{array}$ & 79,05 & 80,95 & 84,76 & 81,59 \\
\hline \multirow[t]{2}{*}{4} & $\begin{array}{l}\text { Memberikan } \\
\text { masukan/pendapat } \\
\text { (pemikiran) yang luwes }\end{array}$ & 79,05 & 86,67 & 85,71 & 83,81 \\
\hline & & & & Rerata & 82,06 \\
\hline
\end{tabular}

Data pada tabel 4 menunjukkan rerata keseluruhan aktifitas siswa sebesar $82,06 \%$ dan berada dalam kategori sangat baik. Hal ini menunjukkan bahwa sebagian besar siswa terlibat secara aktif dalam seluruh kegiatan pembelajaran.

\section{Data Literasi STEM Kelas Eksperimen dan Kontrol}

Penelitian quasi experiment ini melibatkan dua kelompok yaitu kelompok eksperimen dan kelompok kontrol. Dalam pelaksanaan penelitian kelas eksperimen dan kontrol diberikan treatment yang berbeda. Pembelajaran berbasis proyek untuk kelas eksperimen dan pembelajaran menggunakan model cooperative learning tipe Group Investigation untuk kelas kontrol selama tiga kali pertemuan. Kelompok eksperimen berjumlah 35 orang sedangkan kelompok kontrol berjumlah 36 orang.

Literasi STEM diukur dengan menggunakan soal pilihan ganda berjumlah 25 butir. Literasi STEM siswa dilihat melalui nilai gain yang dinormalisasi dari hasil skor pretest dan posttest dari kedua kelas yang berlaku sebagai kelompok eksperimen dan kontrol.

Pelaksanaan penelitian kelas eksperimen dan kontrol diberikan treatment yang berbeda. Pembelajaran berbasis proyek untuk kelas eksperimen dan pembelajaran menggunakan model cooperative learning tipe Group Investigation untuk kelas kontrol selama tiga kali pertemuan. Hasil pretest dan posttest kedua kelas secara rinci disajikan dalam tabel 5 . berikut ini 
Tabel 5. Perbandingan Hasil Pretest dan Posttest Kelas Eksperimen dan Kontrol

\begin{tabular}{lcccc}
\hline \multirow{2}{*}{ Data } & \multicolumn{2}{c}{ Kelas Eksperimen } & \multicolumn{2}{c}{ Kelas Kontrol } \\
\cline { 2 - 5 } & Pretest & Posttest & Pretest & Posttest \\
\hline Nilai terendah (min) & 20 & 44 & 20 & 32 \\
\hline Nilai tertinggi (max) & 60 & 84 & 64 & 76 \\
\hline Rata-rata (mean) & 37,37 & 64,11 & 39,78 & 52,78 \\
\hline Nilai tengah (median) & 36 & 64 & 40 & 52 \\
\hline Modus & 36 & 64 & 36 & 52 \\
\hline Standar deviasi & 9,1 & 9,91 & 10,43 & 10,29 \\
\hline Varians & 82,77 & 98,3 & 108,75 & 105,89 \\
\hline
\end{tabular}

Secara keseluruhan, nilai rata-rata pretest, posttest dan gain literasi STEM pada kelas eksperimen maupun kelas kontrol disajikan pada tabel 6 berikut ini.

Tabel 6. Perbandingan Nilai Rerata Pretest, Posttest dan N_gain Literasi STEM Siswa

\begin{tabular}{lcccc}
\hline \multirow{2}{*}{ Kelas } & \multicolumn{3}{c}{ Nilai Rata-Rata } & \\
\cline { 2 - 4 } & Pretest & Posttest & $\begin{array}{c}\text { N_gain } \\
(\boldsymbol{\%})\end{array}$ & \\
\hline Kelas Eksperimen & 37,37 & 64,11 & 43,00 & Sedang \\
Kelas Kontrol & 39,78 & 52,78 & 22,00 & Rendah \\
\hline
\end{tabular}

Berdasarkan data pada table 6. tersebut, nilai rata-rata pretest untuk kelas eksperimen yaitu 37,3 dan untuk kelas kontrol sebesar 39,78. Nilai rata-rata pretest tersebut menunjukkan bahwa kemampuan awal literasi STEM siswa antara kelompok eksperimen dan kontrol hampir sama. Setelah masing-masing kelas diberikan treatment, terjadi peningkatan literasi STEM pada kedua kelas tersebut. Untuk kelas eksperimen terjadi peningkatan literasi STEM sebesar 43,00\% dengan nilai rata-rata posttest 64,11 dan peningkatan tersebut termasuk pada kategori sedang. Sedangkan untuk kelas kontrol terjadi peningkatan literasi STEM sebesar $22,00 \%$ dengan nilai rata-rata posttest 52,78 dan peningkatan tersebut termasuk dalam kategori rendah. Berikut ini disajikan diagram perbandingan persentase nilai rata-rata pretest, posttest dan $N \_$gain literasi STEM antara kelas eksperimen dan kontrol. 


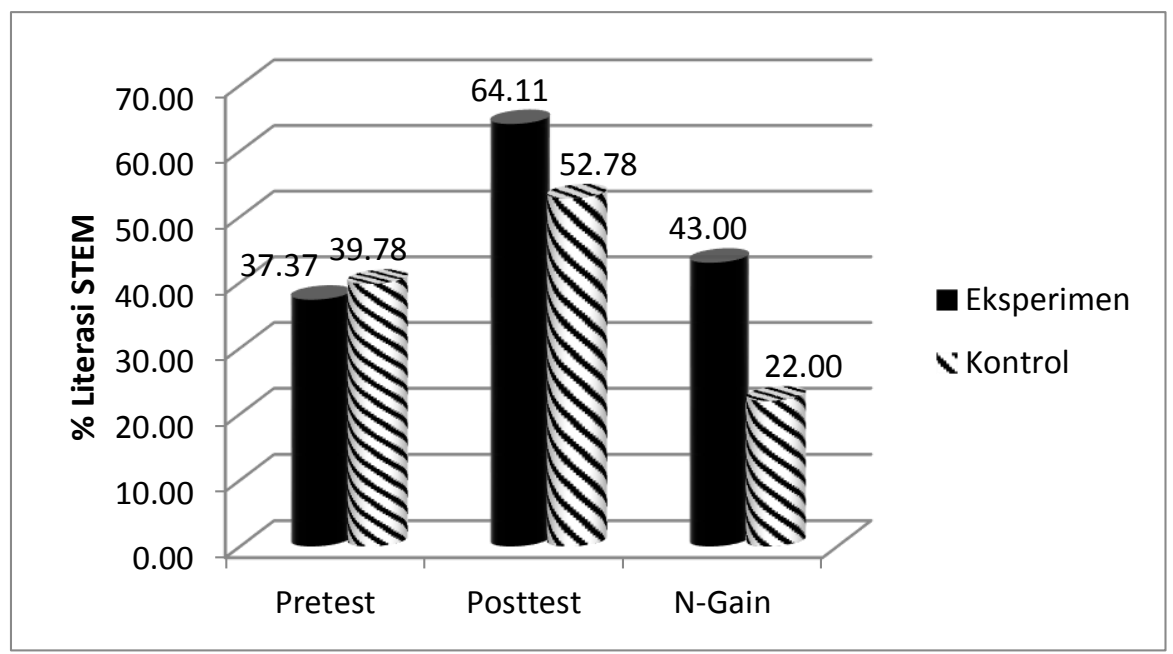

Gambar 1. Histogram Persentase Nilai Rata-rata Pretest, Posttest dan N_gain Literasi STEM

\section{Capaian Literasi STEM Siswa Tiap Indikator}

Deskripsi peningkatan Literasi STEM pada tiap indikator aspek Literasi STEM yang diwakili oleh rata-rata $N \_$gain masing-masing indikator dapat dilihat pada gambar 2. di bawah ini.

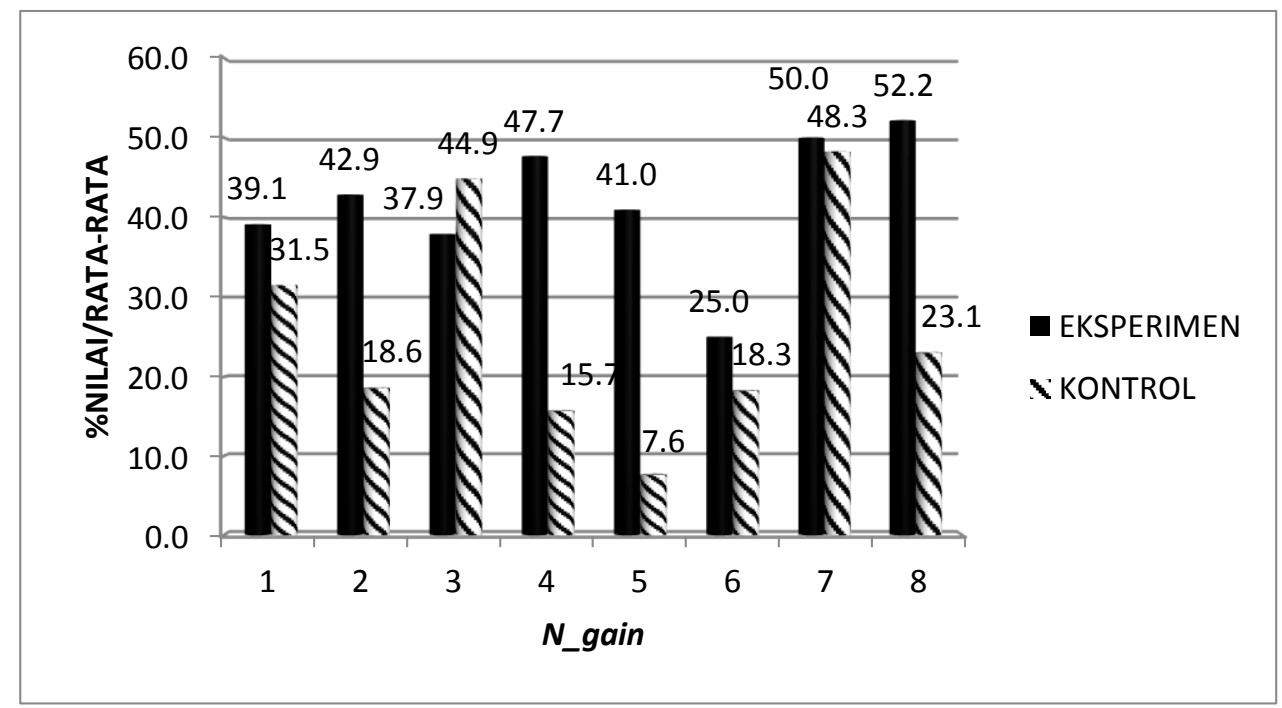

Gambar 2. Histogram Peningkatan Literasi STEM tiap Indikator

Keterangan:

1. Mengajukan pertanyaan (science) dan mendefinisikan masalah (engineering);

2. Mengembangkan dan menggunakan model;

3. Merencanakan dan melakukan investigasi;

4. Menganalisis dan menafsirkan data (Mathematics); 
5. Menggunakan matematika; teknologi informasi dan komputer; dan berpikir komputasi;

6. Membangun eksplanasi (Science) dan merancang solusi (engineering);

7. Terlibat dalam argumen berdasarkan bukti;

8. Memperoleh, mengevaluasi dan mengkomunikasikan informasi.

\section{UJI HIPOTESIS}

Untuk mengetahui perbedaan nilai pretest dan posttest literasi STEM kelas eksperimen dan kelas kontrol dilakukan uji t dua pihak. Uji ini dilakukan dengan menggunakan statistik parametrik yaitu independent sample t-test pada program SPSS 23.0. Hal ini dilakukan karena data pretest dan posttest Literasi STEM berdistribusi normal dan homogen.

Tabel 7. Hasil Uji Perbedaan Hasil Pretest dan Posttest Literasi STEM

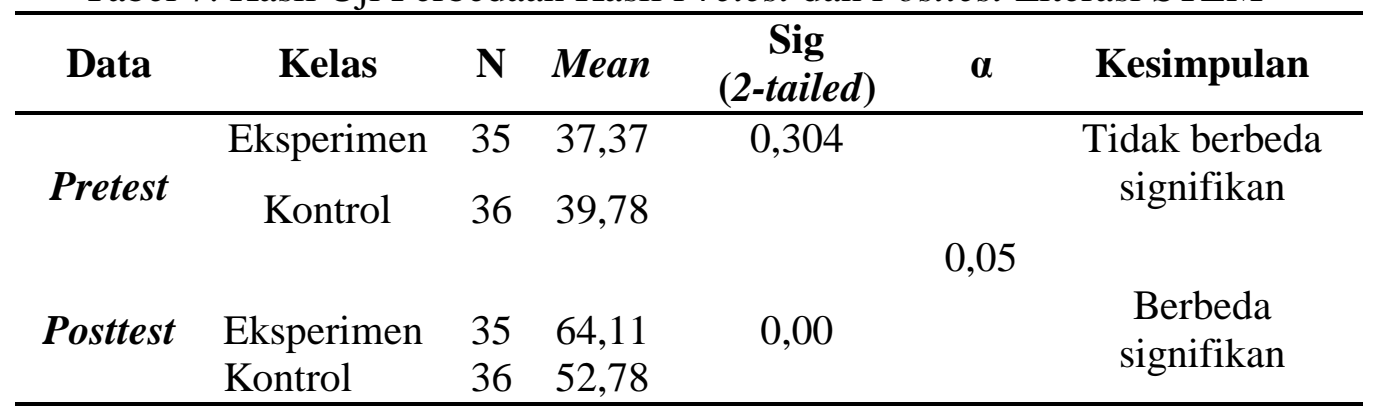

Dari tabel 7. dapat dilihat bahwa nilai sig (2-tailed) untuk hasil pretest adalah 0,304 atau > 0,05 oleh karena itu $\mathrm{H}_{0}$ diterima artinya tidak terdapat perbedaan literasi STEM siswa yang menggunakan model pembelajaran Pembelajaran berbasis proyek dengan siswa yang tidak menggunakan model pembelajaran berbasis proyek. Nilai Posttest dapat dilihat mempunyai nilai sig (2tailed) 0,00 atau $<0,05$ maka $\mathrm{H}_{0}$ ditolak $\mathrm{H}_{1}$ diterima artinya terdapat perbedaan literasi STEM siswa yang menggunakan model pembelajaran berbasis proyek dengan siswa yang tidak menggunakan model pembelajaran berbasis proyek.

Literasi STEM siswa dijaring melalui soal berbentuk pilihan ganda berjumlah 25 soal yang dikembangkan meliputi 8 indikator (National Academy of Science, 2015) diantaranya: (1) Mengajukan pertanyaan (science) dan mendefinisikan masalah (engineering); (2) mengembangkan dan menggunakan model; (3) merencanakan dan melakukan investigasi; (4) Menganalisis dan menafsirkan data (Mathematics); (5) Menggunakan matematika; teknologi informasi dan komputer; dan berpikir komputasi; (6) Membangun eksplanasi (Science) dan merancang solusi (engineering); (7) Terlibat dalam argumen berdasarkan bukti; (8) Memperoleh, mengevaluasi dan mengkomunikasikan informasi. 
Pada dasarnya tingkat literasi STEM kedua kelas sebelum mendapatkan perlakuan adalah setara. Hal ini terlihat dari hasil nilai rata-rata pretest kedua kelompok sekitar 38,6\% (Tabel 6) dan hasil uji perbedaan terhadap nilai rata-rata pretest tersebut yang tidak berbeda secara signifikan. Setelah diberikan treatment berupa pembelajaran berbasis proyek di kelas eksperimen dan pembelajaran menggunakan model pembelajaran kooperatif tipe group investigation pada kelas kontrol, literasi STEM pada kedua kelas tersebut mengalami peningkatan. Untuk kelas eksperimen terjadi peningkatan literasi STEM sebesar $43 \%$ dengan nilai rata-rata posttest $64,11 \%$ dan peningkatan tersebut termasuk pada kategori sedang. Sedangkan untuk kelas kontrol terjadi peningkatan literasi STEM sebesar $22 \%$ dengan nilai rata-rata posttest $52,78 \%$ dan peningkatan tersebut termasuk dalam kategori rendah.

Berdasarkan tabel 7, secara keseluruhan terjadi peningkatan literasi STEM baik di kelas eksperimen maupun pada kelas kontrol. Namun setelah dilakukan uji perbedaan terhadap nilai rata-rata posttest pada kedua kelas tersebut, ternyata hasil uji menunjukkan bahwa terdapat perbedaaan yang signifikan literasi STEM antara kelas eksperimen dan kontrol. Hasil analisis tersebut menunjukkan bahwa penerapan pembelajaran berbasis proyek dapat digunakan dalam meningkatkan literasi STEM siswa. Hal ini sejalan dengan penelitian Craig (2015: hlm 4) yang menyebutkan bahwa salah satu model pembelajaran yang efektif untuk memfokuskan kemampuan di bidang STEM adalah pembelajaran berbasis proyek.

Deskripsi peningkatan Literasi STEM pada tiap indikator aspek Literasi STEM yang diwakili oleh rata-rata $N$ _gain masing-masing indikator. Dari gambar 4.16 dapat dilihat indikator yang menonjol peningkatannya di kelas eksperimen dibandingkan kelas kontrol yaitu indikator 2, 4, 5 dan 8. Sedangkan indikator yang peningkatannya lebih baik di kelas kontrol dibandingkan kelas eksperimen terdapat pada indikator 3. Berikut adalah penjelasan tiap indikator Literasi STEM.

Indikator pertama mengajukan pertanyaan dan mendefinisikan masalah pada kelas eksperimen lebih baik dengan rerata $N \_$gain 39,1\% sedangkan di kelas kontrol sebesar 31,5\%. Nilai $N$ _gain yang lebih baik di kelas Eksperimen karena siswa menjalani sintaks pembelajaran berbasis proyek yang diawali dengan mengajukan pertanyaan essensial dan mendefinisikan masalah dimana siswa bertanya dan merumuskan masalah berkenaan dengan fenomena pencemaran lingkungan yang terjadi di lingkungan sekitar. Peningkatan ini tidak jauh berbeda dengan kelas kontrol artinya kelas kontrol juga memiliki peningkatan kemampuan mengajukan pertanyaan yang hampir sama karena keduanya menggunakan pendekatan saintifik dimana dalam proses inti pembelajaran diawali dengan mengajukan pertanyaan.

Kegiatan mengajukan pertanyaan mendukung proses inkuiri siswa dengan mencari tahu sendiri hal yang ingin diketahuinya kemudian 
mengimplementasikannya dalam kegiatan pembelajaran. Hal ini sejalan dengan penelitian Bell (2010) bahwa pembelajaran berbasis proyek dapat menuntun siswa membangun pengetahuannya sendiri melalui proses inkuiri dan mengimplementasikannya dalam kegiatan penelitian dan mendisain proyek yang menggambarkan hasil pengetahuan mereka.

Indikator kedua mengembangkan dan menggunakan model pada kelas eksperimen memiliki $N_{\text {_gain }}$ yang jauh lebih baik dibandingkan kelas kontrol yaitu sebesar 42,9\% sedangkan kelas kontrol sebesar 18,6\%. Hal ini terjadi karena pada pembelajaran berbasis proyek siswa melakukan sintaks ke-3 pembelajaran berbasis proyek yaitu mendesain atau merancang proyeknya sendiri berupa alat daur ulang limbah secara mandiri, membuat inovasi atau mengembangkan dari alat yang sudah ada. Pembelajaran berbasis proyek mampu meningkatkan kualitas pembelajaran siswa dalam materi tertentu dan menjadikan siswa mampu mengaplikasikan satu pengetahuan tertentu dalam konteks tertentu (Doppelt, 2005, hlm. 10). Kegiatan ini berlangsung pada pertemuan ke-2 siswa merancang proyeknya kemudian sketsa model rancangan alat daur ulang limbah dituangkan dalam LKS.

Indikator ketiga yaitu merencanakan dan melakukan investigasi kelas eksperimen memiliki nilai $N \_$gain yang lebih rendah 37,9\% dibandingkan kelas kontrol 44,9\%. Hal ini bisa terjadi dikarenakan siswa pada kelas eksperimen lebih fokus pada perancangan alat pengolahan limbah dibandingkan melakukan investigasi terhadap penyebab permasalahan lingkungan. Siswa pada kelas eksperimen melakukan kegiatan investigasi dengan menganalisis macam-macam limbah di sekolah mengidentifikasi kemudian melakukan rancangan alat penanggulangan limbah. Berbeda halnya dengan kelas kontrol yang menggunakan model pembelajaran kooperatif tipe grup investigasi dimana setiap kelompok menjalankan sintaks pembelajaran grup investigasi yaitu melaksanakan investigasi permasalahan lingkungan dengan cara mengumpulkan informasi melalui observasi dan wawancara, menganalisis data, serta membuat kesimpulan.

Indikator keempat yaitu menganalisis dan menafsirkan data pada kelas eksperimen memiliki perolehan $N \_$gain lebih tinggi yaitu sebesar 47,7\% sedangkan pada kelas kontrol sebesar $15,7 \%$. Hal ini bisa terjadi dikarenakan siswa pada kelas ekperimen mengalami pembelajaran berbasis proyek dituntut untuk menganalisa fenomena lingkungan yang terjadi dengan menganalisis macam-macam limbah, kategori limbah, jenis dan penanggulangannya kemudian menuangkannya dalam bentuk display data, diagram dan tabel sehingga siswa dapat memahami hubungan antar data yang telah mereka kumpulkan.

Indikator kelima yaitu Menggunakan matematika pada kelas eksperimen memiliki $N \_$gain lebih tinggi yaitu sebesar $41,0 \%$ sedangkan pada kelas kontrol sebesar 7,6\%. Hal ini bisa terjadi karena pada siswa kelas eksperimen melakukan 
sintaks pembelajaran mendesain atau merancang alat penanggulangan limbah dimana mereka mengerahkan kemampuan matematikanya dalam menghitung ukuran alat yang dirancang, menghitung komposisi bahan, membuat perbandingan bahan yang digunakan, menghitung rincian biaya yang dibutuhkan. Dalam proses mendesain ini dapat memotivasi siswa untuk belajar matematika dan konsep sains yang memungkinkan terciptanya teknologi baru (Stohlmann, 2012). Pembelajaran berbasis proyek lebih cocok untuk pengajaran interdisipliner karena secara alami melibatkan banyak keterampilan akademik yang berbeda, seperti membaca, menulis, dan matematika dan cocok untuk membangun pemahaman konseptual melalui asimilasi mata pelajaran yang berbeda (Capraro, 2013, hlm. 52).

Indikator keenam yaitu membangun eksplanasi dan merancang solusi memiliki $N \_$gain lebih tinggi di kelas eksperimen yaitu sebesar 25,0\% sedangkan pada kelas kontrol sebesar $18,3 \%$ hal ini bisa terjadi karena lingkungan belajar pada pembelajaran berbasis proyek membuat siswa menjadi lebih aktif memecahkan masalah-masalah yang kompleks. Siswa mempunyai pilihan untuk menyelidiki topik-topik yang berkaitan dengan masalah dunia nyata, saling bertukar pendapat antara kelompok yang membahas topik yang berbeda, mempresentasikan proyek atau hasil diskusi mereka. Siswa juga lebih menghargai lingkungannya karena keterampilan memecahkan masalah yang mereka dapatkan bermanfaat bagi kehidupan sehari-hari.

Guru tidak membedakan perlakuan di kedua kelas dengan memberikan kesempatan seluas-luasnya kepada siswa dalam membangun eksplanasi dan memunculkan berbagai macam perspektif yang berbeda pada siswa hal tersebut juga bisa mengembangkan keterampilan berpikir tingkat tinggi siswa (Kemdikbud, 2015). Menurut Thomas, 2000, hlm. 8-18, pembelajaran berbasis proyek juga lebih efektif dalam peningkatan kemampuan pemecahan masalah siswa. Hal ini sejalan dengan penelitian Tseng, et al. (2013) yang menunjukkan hasil bahwa dengan pembelajaran berbasis proyek dapat meningkatkan kemampuan siswa memecahkan masalah yang ada di dunia nyata. Penelitian Bell (2010) juga menyimpulkan pembelajaran berbasis proyek meningkatkan kemampuan pemecahan masalah atau melatih siswa menjadi seorang problem solver.

Indikator ketujuh yaitu terlibat dalam argumen berdasarkan bukti pada kelas eksperimen memperoleh $N \_$gain yaitu sebesar 50,0\% sedangkan pada kelas kontrol sebesar 48,3\%. Peningkatan ini tidak jauh berbeda di kedua kelas ini bisa terjadi karena kedua kelas sudah memiliki kemampuan berargumen yang baik, siswa sudah terbiasa terlibat aktif dalam diskusi dan menyatakan pendapat. Pada kelas eksperimen yang menggunakan pembelajaran berbasis proyek mempunyai kelebihan yaitu peningkatan kemampuan berpikir siswa berargumen tidak hanya berdasar informasi yang dibaca saja, tetapi melibatkan siswa untuk belajar 
mengembangkan masalah, mencari jawaban dengan mengumpulkan informasi, berkolaborasi dan menerapkan pengetahuan yang dipahami untuk menyelesaikan permasalahan dunia nyata (Kemdikbud, 2015).

Indikator kedelapan yaitu memperoleh mengevaluasi dan mengkomunikasikan informasi pada kelas eksperimen memperoleh $N \_$gain lebih tinggi yaitu sebesar 52,2\% sedangkan pada kelas kontrol sebesar 23,1\%. Pembelajaran dengan menggunakan model pembelajaran berbasis proyek mengarahkan siswa untuk membuat sebuah proyek. Hasil dari pengerjaan proyek, siswa secara mandiri akan membangun pengetahuannya, meningkatkan kemampuan memecahkan masalah, mengembangkan keterampilan berpikir dan komunikasi. Siswa yang mempunyai kemampuan di bidang STEM dapat mengembangkan keterampilan yang dibutuhkan di abad 21 seperti keterampilan teknologi, mahir berkomunikasi dan pemecahan masalah (Bell, 2010, hlm. 39). Penelitian lainnya yaitu penelitian Jaka Afriana (2016) dimana siswanya memberikan respon pembelajaran berbasis proyek menarik dan memotivasi, dapat membantu memahami materi ajar, membentuk sikap kreatif, dan siswa semakin menyadari pentingnya menjaga lingkungan.

Rata-rata skor tanggapan siswa terhadap penerapan pembelajaran berbasis proyek pada materi pencemaran lingkungan secara keseluruhan adalah sebesar 84,11\%. Dengan demikian dapat disimpulkan bahwa hampir seluruh siswa memberikan respon positif, senang, percaya diri dan puas terhadap pembelajaran berbasis proyek pada materi pencemaran lingkungan selama kegiatan penelitian. Hal ini sejalan dengan penelitian Tseng, et.al. (2013) yang menyatakan bahwa pembelajaran berbasis proyek dapat meningkatkan minat siswa mempelajari bidang keilmuan Sains Teknologi Enjiniring dan Matematika. Penelitian ini juga sejalan dengan penelitian Baran \& Maskan (2010: 252) yang menyatakan bahwa siswa lebih aktif diajar dengan menggunakan pembelajaran berbasis proyek dan pembelajaran menjadi lebih menyenangkan. pembelajaran berbasis proyek juga dapat meningkatkan motivasi siswa untuk belajar (Bell,2010). Pembelajaran berbasis proyek memberikan tantangan baru bagi siswa, memancing rasa ingin tahu yang besar, mengembangkan imajinasi dan sukses belajar di bidang teknologi (Doppelt, 2005).

Kegiatan refleksi di akhir pembelajaran siswa mengakui kesulitan dalam menentukan alat penanggulangan limbah kemudian keterbatasan waktu dan menentukan waktu untuk bekerja kelompok menjadi kendala mengingat pembelajaran berbasis proyek tidak hanya mengandalkan waktu di dalam kelas mereka juga harus menyelesaikan proyek di luar jam pelajaran. Pada kelompok yang menangani limbah beracun B3 juga merasa kesulitan dalam mencari referensi alat di internet karena banyaknya referensi tersebut membuat siswa bingung menentukan alat yang paling tepat. 
Ketika siswa telah menemukan ide dalam menentukan alat pengolahan limbah sebagian besar siswa merasa senang, lega dan merasa bangga. Siswa sangat berharap rancangan alat pengolahan limbah yang mereka buat bisa ditindaklanjuti dalam kegiatan ekstrkurikuler KIR yang ada di SMAN 1 Cigombong.

Model pembelajaran berbasis proyek memberikan kesempatan kepada siswa untuk terlibat secara langsung dan bertanggung jawab penuh atas pembelajaran. Karena semuanya dilakukan berdasarkan hasil diskusi siswa dengan anggota kelompok maupun dengan guru. Seperti contohnya deadline penyerahan tugas. Bukan guru yang menentukan deadline tersebut tetapi didiskusikan bersama-sama antara guru dan siswa. Hal ini agar siswa tidak merasa terbebani dengan tugas proyek yang mereka kerjakan. Proses kolaborasi antar siswa juga terlihat dari tanggungjawab semua anggota kelompok dalam mengerjakan intruksi yang diberikan, tidak ada anggota kelompok yang tidak bekerja, terlihat semua kelompok membagi tugas anggotanya secara proporsional tapi tetap saja ada anggota kelompok yang terlihat pasif.

Salah satu tahap dalam pembelajaran berbasis proyek adalah pemberian evaluasi. Hal ini bertujuan untuk mengetahui tingkat pemahaman setiap anggota kelompok terhadap proyeknya dan juga untuk memberikan informasi kepada kelompok lain. Dalam hal ini bukan hanya perwakilan kelompok saja yang mengerjakan dan menguasai materi proyek tetapi semua anggota kelompok harus menguasai materi proyek yang dibuatnya. Dengan demikian siswa akan lebih aktif untuk mencari referensi, membaca dan menganalisis sumber-sumber yang relevan dengan proyeknya untuk menambah informasi dan pengetahuan. Tetapi masih ada siswa yang kurang berpartisipasi dalam kelompok, akibatnya siswa kurang menguasai materi proyek. Hal ini dapat terlihat pada saat dilakukan evaluasi dan saat presentasi hasil proyek masih ada siswa yang kurang menguasai materi presentasi. Hal ini menjelaskan bahwa penumbuhan karakter tanggungjawab tidak bisa dilakukan dalam waktu singkat. Butuh pembiasaan dalam jangka waktu yang panjang dan senantiasa selalu ditanamkan oleh guru melalui pendidikan penguatan karakter.

Dengan pembelajaran berbasis proyek dapat disimpulkan siswa mempunyai kesadaran pentingnya Literasi STEM dan mampu mengembangkan keterampilan abad ke-21 yang tercermin dari indikator STEM yang muncul selama pembelajaran seperti keterampilan inkuiri ilmiah, memecahkan masalah, mempunyai kemampuan untuk mendesain alat untuk menangani permasalahan di dunia nyata, berkolaborasi dan mengkomunikasikan informasi. Penggunaan model pembelajaran berbasis proyek diharapkan mampu mencetak siswa yang kompetitif dan diperhitungkan di dunia kerja khususnya pada bidang STEM di masa yang akan datang. Siswa yang punya kemampuan di bidang STEM dapat 
mengembangkan keterampilan yang dibutuhkan dalam berkompetisi pada abad ke-21 (Sanders, 2009; Becker \& Park, 2011).

\section{PENUTUP}

Berdasarkan hasil penelitian, analisis dan pembahasan maka diperoleh kesimpulan bahwa keterlaksanaan pembelajaran biologi menggunakan model pembelajaran berbasis proyek pada materi pencemaran lingkungan sudah terlaksana sesuai dengan yang direncanakan. Karakteristik model pembelajaran berbasis proyek 1) Meningkatkan literasi STEM siswa karena di setiap sintaksnya melatihkan aspek-aspek literasi STEM siswa; 2) Bersifat student centered; 3) Melatih kemampuan inkuiri siswa; 4) Menjadikan siswa seorang pemecah masalah atau problem solver; 5) Membuat siswa mahir mengkomunikasikan informasi yang diperoleh; 6) Melatih kemampuan mendesain alat untuk mengatasi permasalahan lingkungan.

Dari hasil analisis uji hipotesis terdapat perbedaan yang signifikan hasil akhir. Literasi STEM pada kelas eksperimen dengan kelas kontrol yang artinya hasil akhir Literasi STEM kelas Eksperimen lebih baik dibandingkan dengan di kelas kontrol. Literasi STEM siswa dengan menggunakan model pembelajaran berbasis proyek pada materi Pencemaran Lingkungan meningkat secara signifikan. Peningkatan literasi STEM pada kelas eksperimen termasuk dalam kategori sedang, sedangkan untuk kelas kontrol termasuk dalam kategori rendah. Siswa memberikan tanggapan positif terhadap model pembelajaran berbasis proyek pada materi pencemaran lingkungan dalam meningkatakan literasi STEM siswa walaupun terdapat kendala dalam manajemen waktu dan kesulitan dalam menentukan rancangan alat pengolahan limbah.

Bagi guru model pembelajaran berbasis proyek dapat dijadikan sebagai salah satu alternatif model pembelajaran harus sering dilatihkan pada siswa untuk menumbuhkan literasi STEM. Untuk penelitian lebih lanjut diharapkan penerapan model pembelajaran berbasis proyek pada konsep lainnya serta diharapkan ada penelitian yang melibatkan kolaborasi mata pelajaran lain yang mendukung ketercapaian literasi STEM yang lebih tinggi.

\section{REFERENSI}

Afriana, Jaka. (2016). Project Based Learning Integrated to STEM to Enchance Elementary School's Students Scientific Literacy. Jurnal Pendidikan IPA Indonesia, 5 (2), 261-267.

Baran, M. \& Maskan, A. (2010). The Effect of Project-Based Learning On PreService Physics Teachers' Electrostatic Achievements. Cypriot Journal of Educational Sciences , 5, 243-257 
Becker, K. \& Park, K. (2011). Effects of integrative approaches among science, technology, engineering, and mathematics (STEM) subjects on students'learning: A preliminary meta-analysis. Journal of STEM Education, 12, (5\& 6), 23-37.

Bell, S. (2010). Project Based Learning for the 21th Century: Skills for the Future. The Clearing House, 83, 39-43.

Capraro. (2013). STEM Project-Based Learning : An Integrated Science, Technology, Engineering, and Mathematics (STEM) Approach (second ed). Rotterdam : Sense Publishers.

Cook. (2012). Preparing Biology Teachers to Teach Evolution in a Project- Based Approach. Winter, 21 (2) , 18-30

Craig, T. T. (2015). A Statistical Analysis of the Effects of Project-Based Learning on Student High School and College Outcomes. (Dissertation).The University of Texas at Austin.

Doppelt, Y. (2005). Assessment of Project Based Learning in a mechatronics context. Journal of Technology Education, 16 (2), 7-24.

Fraenkel J R \& Wallen N E. (2009). How to Design and Evaluate Research in Education (7th ed). Boston : Mc. Graw-Hill Publishing Company.

Kemdikbud. (2015). Materi pelatihan guru implementasi kurikulum 2013 tahun 2015: Mata pelajaran BIOLOGI SMA/SMK. Jakarta: Kementerian Pendidikan dan Kebudayaan.

Kılınç, A. (2010). Can Project-Based Learning Close the Gap?. Turkish Student Teachers and Proenvironmental Behaviours. International Journal of Environmental \& Science Education, 5, 495-509.

National Academy of Science. (2015). National Academy of Science. [Online]. Retrieved from http://www.nap.edu/openbook.php?re cord_id=4962

Özer, D., Z., \& Özkan, M. (2012). The Effect of the Project Based Learning on the Science Process Skills of the Prospective Teachers of Science. Journal of Turkish Science Education, 9 (3), 131-136.

Sanders, M. (2009). STEM, STEM education, STEMmania. The Technology Teacher, 68 (4), 20-26.

Stohlmann, M.; Moore, T. J.; \& Roehrig, G. H. (2012). Considerations for Teaching Integrated STEM Education. Journal of Pre-College Engineering Education Research (J-PEER), 2 (1), 4.

Thomas, J. W. (2000). A review of Research on PBL. Vol/2 . [Online]. Retrieved from http://www.bobpearlman.org/BestPractices/PBLResearch.pdf.

Tseng, et al. (2013). Attitudes Towards Science, Technology, Engineering and Mathematics (STEM) in a Project Based Learning (PjBL) Environment. International Journal Technology and Design Education, 23, 87-102. 